\title{
INFLUENCE OF DIFFERENT MAIZE VARIETIES ON THE RICE WEEVIL Sitophilus oryzae (L) INFESTATION UNDER LABORATORY CONDITIONS. \\ Awadalla,S.S. ; G.M.M.Zayed ${ }^{\star \star}$; A.R.Ahmed* and A.S.Hashem ${ }^{\star *}$ \\ * Economic Entomology Department, Faculty of Agriculture, Mansoura University, Egypt. \\ ** Plant production research Institute , Sakha , Kafr El-Sheikh , Egypt.
}

\begin{abstract}
Choice and non-choice tests were carried out to determine the influence of certain maize varieties on the rice weevil, Sitophilus oryzae (L) infestation under laboratory conditions. Regarding to non-choice tests on different maize varieties, data revealed that, Tri-Hybrid 353 yellow variety was the highest weight after damage. while Tri-Hybrid 311 white variety was the highest percentage weight loss and lowest weight after damage. In addition, Tri-Hybrid 353 yellow variety was the longest total developmental period and lowest number of $\mathrm{F} 1$ while Tri-Hybrid 311 white variety was the shorter total developmental period and highest number of $\mathrm{F} 1$ progeny. In respect to free choice on different maize varieties, data revealed that, Tri-Hybrid 353 yellow variety was the highest weight after damage, while Tri-Hybrid 311 white variety was the highest percentage weight loss and lowest weight after damage. On the other hand, the index of susceptibility (IS) among the varieties tested showed that Tri-Hybrid 311 white was moderately susceptible for different maize grains varieties and other varieties were moderately resistant.
\end{abstract}

\section{INTRODUCTION}

Maize, Zea mays L., is the second most produced cereal after wheat in the world. It is cosmopolitan in distribution and widely consumed by man and his animals (Makate, 2010). About 50 maize species exist and grains vary in colour, texture, shape and size. Maize grains are rich in Vitamins $A, C$ and $E$, carbohydrates, essential minerals and protein. Worldwide production of maize in 2011 was $883,460,240$ tonnes with the largest producer, the United States, producing $35.5 \%$. Africa produces $7.4 \%$ and the second largest African producer (after South Africa) was Nigeria with 9,180,270 tonnes (FAO, 2013).

During post-harvest storage, maize grains are vulnerable to many insects. Among those, Angoumois grain moth, Sitotroga cerealella (Olivier), lesser grain borer Rhyzopertha dominica (F.), weevils complex Sitophlilus spp., Khapra beetle Trogoderma granarium Everts and red flour beetle , Tribolium castaneum (Herbst) are very important (Lohar et al., 1997; Ebeling, 2002). But most damage is done during storage. Damaged grains have reduced nutritional values, low percent germination and reduced weight and market values, respectively. Worldwide seed losses ranging from 20 to $90 \%$ have been reported for untreated maize due to the maize weevil , S. zemais (Giga et al., 1991).

The rice weevil, Sitophilus oryzae (L.), is a cosmopolitan pest which is considered to be one of the most destructive species in stored grain. It is classified as a primary pest, which can easily infest sound seeds, enabling 
other species (the secondary pests), which are not capable of breeding on intact grains, to cause additional damage (Hill, 1990; Rees, 1995). Since its larvae develop in the internal part of the kernels, the infestation is not visible at the first stages. Moreover, $S$. oryzae has developed a considerable level of resistance, to many traditional residual protectants (Arthur, 1996). For instance, the rice weevil is considered to be one of the most resistant storedproduct insect species to pyrethroids, and usually cannot be controlled by application rates that are effective against most other stored-grain beetle species (Samson and Parker, 1989; Arthur, 1992, 1994, 1999).

Therefore, the aim of the present work is to study the influence of different maize varieties on the rice weevil S.oryzae infestation.

\section{MATERIALS AND METHODS}

Relative susceptibility of some maize varieties to S.oryzae was carried out under laboratory conditions at stored product pest laboratory, Sakha Agricultural Research Station.

The rice weevil S.oryzae was raised on a susceptible local maize variety in the laboratory. The maize grains were initially stored for two weeks at $-4{ }^{\circ} \mathrm{C}$ to eliminate different stages of storage pests that might be present in the kernels and remove seeds with visible damage symptoms. Grains were then transferred into transparent plastic buckets and kept in a rearing room for two weeks to attain stable environmental conditions. Small windows $(10 \mathrm{~cm} \times 10 \mathrm{~cm})$ were created on the lid and side of the buckets and covered with nylon mesh for proper ventilation. Newly emerged S.oryzae was introduced into the buckets containing the disinfested maize. Ten days after introduction, adults were removed from each bucket and the containers were observed beginning from 20 days after the insect's introduction for emergence of offspring. The insect's culture was established to supply adequate number of the insects of similar age for the experiments.

The susceptibility experiments were carried out on four varieties of maize namely Tri-Hybrid 311 white, Tri-Hybrid 353 yellow, Single-Hybrid 10 white and Single-Hybrid 173 yellow. All are obtained from the Crop Research Institute, Sakha Agricultural Research Station, Kafr -El-Sheikh, Ministry of agriculture.

Enough samples of maize grains were firstly sieved to remove stone, dust and insects. The grains were then sterilized by freezing for $24: 48 \mathrm{~h}$ at $18:-22^{\circ} \mathrm{C}$ to be assured freedom from any insect infestation. All grains were maintained in an incubator at a constant temperature of $29 \pm 1{ }^{\circ} \mathrm{C}$ and $65 \pm 5 \%$ R.H. for two weeks to obtain equilibration moisture content with this R.H. (Ezz, 1976). To evaluate the relative susceptibility of the tested maize varieties, two sets of experiments were applied. The first was a free choice infestation test and the other was a non-choice infestation test. 


\section{Non-choice infestation test:}

Non-choice test method in which pre-determined the insects were introduced to each jar was used for the study (Abebe et al., 2009). Twenty grams of each variety was weighed into plastic Petri dishes in three replicates. The plastic material allowed ventilation and prevented insects from escaping. Twenty emerged unsexed adult insects aged between 0 and 5 days were then introduced into the Petri dishes containing the grains. The insects were allowed to lay eggs on the grains for 10 days after which they were removed and checked for adult mortality. The insects that were dead and those that were alive were counted and recorded separately for each dish. The entire set up was then left in the laboratory at $26{ }^{\circ} \mathrm{C}$ and $75 \% \mathrm{RH}$ until the first adults of the $\mathrm{F} 1$ generation emerged.The total number of $\mathrm{F} 1$ adults was determined on each maize variety and median development time (MDT) was calculated as the time (days) from the middle of oviposition period to the emergence of $50 \%$ of these adults. The data was used to calculate the index of susceptibility.

To assess each maize variety seed damage (seeds with hole (s)) and grain weight loss. Seed damage was expressed as a proportion of the total number of seeds sampled (Abebe et al., 2009). The count and weight method of Gwinner et al. (1996) was used to determine seed weight loss using the formula:

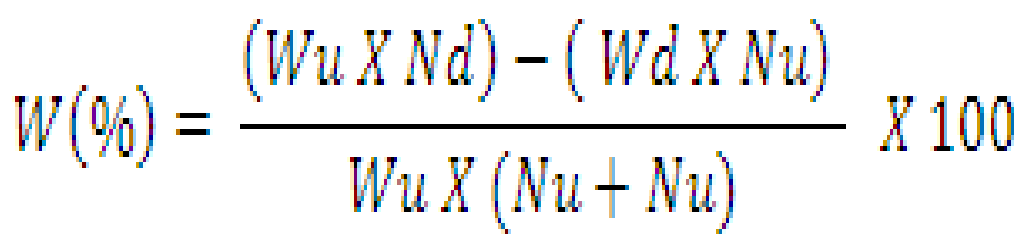

Where, $\mathrm{W}$ is the weight loss (\%), Wu is the Weight of undamaged seed, $\mathrm{Nu}$ is the number of undamaged seed, $\mathrm{Wd}$ is the weight of damaged seed and $\mathrm{Nd}$ is the number of damaged seed.

\section{Choice infestation test:-}

In this experiment, glass jars accommodates four varieties of maize grain (with three replicates) for S.oryzae was used as choice chamber. Twelve Petri dishes ( $9 \mathrm{~cm}$ diameter) each contains $20 \mathrm{gm}$ of a variety was used. Three hundred adults of each tested insect (150 pairs 10 day old) were placed in the center part of each jar to give the insects a free choice to oviposit on any variety. The experiment was conducted at the conditions of $\left(27^{\circ} \mathrm{C}\right.$ and $70 \%$ R.H. $)$. The parents were removed after ten days of treatment. After 60 days, the percent of damage and grain loss was estimated. Analysis of variance and Duncan's multiple range tests (1955) were performed to rank the varieties according to their susceptibility to the insect. 


\section{Awadalla,S.S. et al.}

\section{Index of susceptibility:}

The Dobie index of susceptibility was used as the criterion to separate varieties into different resistance groups (Dobie, 1974). The index of susceptibility is given by the formula:

$$
\mathrm{IS}=\frac{\mathrm{LogeX}}{\mathrm{MDP}} \times 100
$$

Where, IS is the Dobie's index of susceptibility, $\log _{e}{ }^{x}$ is the natural logarithm of the total number of F1 progeny emerged and MDP is the Median development period.

The Dobie Index was used to classify the maize varieties into susceptibility groups following the scales as follows: scale index of $\leq 4$ was classified as resistant; scale index of 4.1-6.0 as moderately resistant; scale index of 6.1-8.0 as moderately susceptible; scale index of $8.1-10$ as susceptible; and scale index of $>10$ was classified as highly susceptible.

\section{Data analysis:}

All data collected were subjected to analysis of variance (ANOVA) procedures (SAS, 2008). Tukey test were used to detect mean differences between treatments. Data with regard to percent adult mortality, seed damage and weight loss were subjected to angular-transformation while numbers of $\mathrm{F} 1$ progenies were log transformed in order to ensure assumptions of ANOVA before analysis. Then, the transformed data were analyzed using one-way ANOVA. Tukey standardized "Honestly Significant Difference" (HSD) tests were used to differentia.

\section{RESULTS AND DISCUSSION}

Choice and non-choice tests were carried out to determine the preferred maize varieties for S.oryzae under laboratory conditions. Some biological parameters for both insects were used as an indicator of the insect preference. These parameters were weight after damage, number of emerged progeny the percentage of weight loss, adult mortality and median development period (MDP) or $F_{1}$ longevity.

\section{Non-choice test:}

\subsection{Influence of different varieties of maize on adult mortality, $F_{1}$ progeny} and median development:

Date presented in Table (1) showed the influence of different varieties of maize on biological parameters of S.oryzae. In respect to the percentage of adult mortality, $F_{1}$ emerged progeny and median development period. Maximum and the highest weevil's adult mortality was recorded from Tri-Hybrid 353 yellow $(3.7 \pm 0.3 \%)$ followed by Single-Hybrid 173 yellow $(3.3 \pm 0.3 \%)$, Single-Hybrid 10 white $(2.3 \pm 0.3 \%)$ and Tri-Hybrid 311 white $(1.3 \pm 0.3 \%)$. 
Among all the maize varieties tested, Maximum and the numbers of progenies was emerged from Tri-Hybrid 311 white $(224 \pm 0.87)$ and Single-Hybrid 10 white $(195 \pm 1.45)$ while the lowest numbers of progenies was emerged from Tri-Hybrid 353 yellow $(129 \pm 1.2)$.

Table 1: Adult mortality, $F_{1}$ progeny and median development period (MDP) of S.oryzae on different maize varieties caused by S.oryzae according to non-choice test.

\begin{tabular}{|c|c|c|c|}
\hline Maize Varieties & \multicolumn{3}{|c|}{ MEAN \pm SE } \\
\cline { 2 - 4 } & $\begin{array}{c}\text { Adult mortality } \\
\%\end{array}$ & F1 progeny & $\begin{array}{c}\text { median development } \\
\text { period (MDP) }\end{array}$ \\
\hline $\begin{array}{c}\text { Tri-Hybrid } 311 \\
\text { white }\end{array}$ & $1.3 \pm 0.33 \mathrm{~b}$ & $224 \pm 0.87 \mathrm{a}$ & $37.7 \pm 0.33 \mathrm{~b}$ \\
\hline $\begin{array}{c}\text { Single-Hybrid } 10 \\
\text { white }\end{array}$ & $2.3 \pm 0.3 \mathrm{ab}$ & $195 \pm 1.45 \mathrm{ab}$ & $38.7 \pm 0.3 \mathrm{ab}$ \\
\hline $\begin{array}{c}\text { Single-Hybrid } \\
173 \text { yellow }\end{array}$ & $3.3 \pm 0.3 \mathrm{a}$ & $161.33 \pm 1.45 \mathrm{~b}$ & $39.7 \pm 0.8 \mathrm{ab}$ \\
\hline $\begin{array}{c}\text { Tri-Hybrid } 353 \\
\text { yellow }\end{array}$ & $3.7 \pm 0.3 \mathrm{a}$ & $129.61 \pm 1.21 \mathrm{c}$ & $40.7 \pm 0.6 \mathrm{a}$ \\
\hline
\end{tabular}

In the same column, means followed by the same letter are not significantly different according to DMRT at 0.05 level of probability.

The median development period (MDP) ranged from $37.7 \pm 0.33$ days for Tri-Hybrid 311 white to $40.7 \pm 0.6$ days for Tri-Hybrid 353 yellow. Shorter median development period was recorded on variety Tri-Hybrid 311 white 37.7 \pm 0.33 days. Generally, as the median development period increases the $F_{1}$ progeny emergency decrease were as the percentage adult weevil mortality increase. Varieties with high $F_{1}$ progeny emergency tended to have shorter median development period and very minimum percentage adult mortality.

1.2. Influence of different varieties of maize on the percentage of weight after damage and the percentage of weight loss.

Data presented in Table (2) showed the influence of different varieties of maize on the weight after damage and percentage of weight loss caused by S. oryzae reared on different maize grains varieties under laboratory conditions according to non-choice test. Regarding to the weight after damage, Tri-Hybrid 353 yellow was the highest weight after damage $(19.2 \pm 0.12)$ followed by Single-Hybrid 173 yellow (19.1 \pm 0.08$)$, Single-Hybrid 10 white $(18.9 \pm 0.12)$ and Tri-Hybrid 311 white $(18.3 \pm 0.19)$. Where weight before damage $=20 \mathrm{gm}$. 
Awadalla,S.S. et al.

Table 2: Influence of different maize varieties on the weight after damage and the percentage of weight loss caused by S.oryzae according to non-choice test.

\begin{tabular}{|l|c|c|}
\hline Maize Varieties & $\begin{array}{c}\text { Mean of weight after } \\
\text { damage }\end{array}$ & $\begin{array}{c}\text { Mean weight loss } \\
\% \pm \text { SE }\end{array}$ \\
\hline Tri-Hybrid 311 white & $18.3 \pm 0.19 \mathrm{a}$ & $8.5 \pm 0.99$ \\
\hline Single-Hybrid 10 white & $18.9 \pm 0.12 \mathrm{a}$ & $5.5 \pm 0.57$ \\
\hline Single-Hybrid 173 yellow & $19.1 \pm 0.08 \mathrm{a}$ & $4.67 \pm 0.43$ \\
\hline Tri-Hybrid 353 yellow & $19.2 \pm 0.12 \mathrm{a}$ & $3.83 \pm 0.6$ \\
\hline
\end{tabular}

In the same column, means followed by the same letter are not significantly different according to DMRT at 0.05 level of probability.

Moreover, there were non-significant differences between the different maize varieties according to the mean weight after damage.

On the contrary, the highest percentage weight loss was observed in Tri-Hybrid 311 white $(8.5 \pm 0.99 \%)$ followed by Single-Hybrid 10 white $(5.5 \pm 0.57 \%)$, Single-Hybrid 173 yellow $(4.67 \pm 0.43 \%)$ and Tri-Hybrid 353 yellow (3.83 \pm $0.6 \%)$.

\section{Free choice test:}

Data presented in Table (3) showed the influence of different varieties of maize on the weight after damage and percentage of weight loss caused by S. oryzae reared on different maize grains varieties under laboratory conditions according to free choice test. Regarding to the weight after damage, Tri-Hybrid 353 yellow was the highest weight after damage $(18.9 \pm 0.12)$ followed by Single-Hybrid 173 yellow (18.3 \pm 0.19$)$, Single-Hybrid 10 white $(17.9 \pm 0.06)$ and Tri-Hybrid 311 white $(17.3 \pm 0.08)$.

On the contrary, the highest percentage weight loss was observed in TriHybrid 311 white $(13.67 \pm 0.43)$ followed by Single-Hybrid 10 white $(10.67 \pm$ $0.33)$, Single-Hybrid 173 yellow (8.5 \pm 0.99$)$ and Tri-Hybrid 353 yellow (5.5 \pm $0.57)$.

Where weight before damage $=20 \mathrm{gm}$.

In the same columm, means followed by the same letter are not significantly different according to DMRT at 0.05 level of probability.

These results are in agreement with those of Tadesse (1991) and Tefera et al. (2011) indicated that the extent of damage during storage depends on the number of emerging adults during each generation and the duration of each life cycle and varieties permitting more rapid and higher levels of adult emergence are more seriously damaged. Differential reaction of maize varieties to maize weevil have been reported by several authors (Giga et al., 1991; Arnason et al., 1993). Similarly, Garcia-Lara et al. (2004) indicated that progeny emergency tended to be higher in susceptible genotypes than in resistant ones.

Index of susceptibility (IS): 
Table 3: Influence of different maize varieties on the weight after damage and the percentage of weight loss caused by S.oryzae according to Free Choice test.

\begin{tabular}{|l|c|c|}
\hline Maize Varieties & $\begin{array}{c}\text { Mean of weight } \\
\text { after damage }\end{array}$ & $\begin{array}{c}\text { Mean weight loss } \\
\% \pm \text { SE }\end{array}$ \\
\hline Tri-Hybrid 311 white & $17.3 \pm 0.08 \mathrm{~b}$ & $13.67 \pm 0.76$ \\
\hline Single-Hybrid 10 white & $17.9 \pm 0.06 \mathrm{ab}$ & $10.67 \pm 0.33$ \\
\hline Single-Hybrid 173 yellow & $18.3 \pm 0.19 \mathrm{ab}$ & $8.5 \pm 0.99$ \\
\hline Tri-Hybrid 353 yellow & $18.9 \pm 0.12 \mathrm{a}$ & $5.5 \pm 0.57$ \\
\hline
\end{tabular}

Table 4: Index of susceptibility (IS) of maize varieties to rice weevil S.oryzae:

\begin{tabular}{|l|c|c|}
\hline Maize Varieties & Dobie's IS & Classification \\
\hline Tri-Hybrid 311 white & 6.23 & Moderately susceptible \\
\hline Single-Hybrid 10 white & 5.92 & Moderately resistance \\
\hline Single-Hybrid 173 yellow & 5.2 & Moderately resistance \\
\hline Tri-Hybrid 353 yellow & 5.56 & Moderately resistance \\
\hline
\end{tabular}

Significantly differences $(p<0.05)$ were observed in the index of susceptibility (IS) among the varieties tested (Table 4). The IS in S.oryzae were 5.2, 5.56, 5.92 and 6.23 for Single-Hybrid 173 yellow, Tri-Hybrid 353 yellow , Single-Hybrid 10 white and Tri-Hybrid 311 white, respectively. Whereas, TriHybrid 311 white was moderately susceptible for different maize grains varieties and other varieties were moderately resistant.

These results are in agreement with those of according to Horber (1988). The index of susceptibility is based on the assumption that the more $F_{1}$ progeny and the shorter the duration of the development, the more susceptible the seeds would be. Abraham (1991) indicated that the extent of damage during storage depends upon the number of emerging adults during each generation and the duration of each life cycle and seeds permitting more rapid and higher levels of adult emergence will be more seriously damaged. Several maize varieties, including local land races, have been characterized as sources of resistance to S. zeamais (Giga and Mazarura, 1991; Arnason et al. 2004) and some sources of resistance have been incorporated into elite maize lines. 


\section{REFERENCES}

Abebe, F., T. Tefera, S. Mugo, Y. Beyene and S. Vidal. (2009). Resistance of maize varieties to the maize weevil Sitophilus zeamais (Motsch.) (Coleoptera: Curculionidae) . Afr. J. Biotechnol., 8: 59375943.

Abraham T (1991). The biology, significance and control of the maize weevil, Sitophilus zeamais Motsch. (Coleoptera: Curculionidae) on stored maize. M.Sc. Thesis presented to the School of Graduate Studies of Haramaya University of Agriculture, Ethiopia. p. 250.

Arnason J.T, B .Baum, J .Gale, J.D.H. Lambert, D .Bergvinson, B .J. R. Philogene, J.A, Serratos , J .Mihm and D.C.Jewell (2004). Variation in resistance of Mexican landraces of maize to maize weevil Sitophilus zeamais, in relation to taxonomic and biochemical parameters Euphytic, 74: 227-336.

Arnason JT, J.D.H Lambert, J .Gale and J. Mihm (1993). Is Quality Protein Maize more susceptible than normal varieties to attack by the Maize Weevil, Sitophilus zeamais? Postharvest Biol. Technol. 2: 349-358.

Arthur, F.H. (1992). Residual efficacy of chlorpyriphos-methyl+bioresmethrin and chlorpyriphos methyl+resmethrin for controlling lesser grain borers (Coleoptera: Bostrychidae), rice weevils (Coleoptera: Curculionidae), and red flour beetles (Coleoptera: Tenebrionidae) in stored wheat.J.Econ.Entomol.85: 570-575.

Arthur, F.H. (1994). Efficacy of unsynergised deltamethrin and deltamethrin+chlorpyriphos-methyl combinations as protectants of stored wheat and stored corn (maize).J.Stored Prod. Res.30, 87-94.

Arthur, F.H. (1996). Grain protectants: current status and prospects for the future.J. Stored Prod.Res.32, 293-302.

Arthur, F.H., (1999). Knockdown, mortality and progeny production of lesser grain borers (Coleoptera: Bostrychidae) and rice weevils (Coleoptera: Curculionidae) exposed for short intervals on wheat treated with cyfluthrin. J. Econ. Entomol.92, 1198-1205.

Dobie P (1974). The laboratory assessment of the inherent susceptibility of maize varieties to post harvest infestation by Sitophilus zeamais Motsch. (Coleoptera: Curculionidea) infesting field corn. J. Entomol. Sci. 21: 367-375.

Duncan, D.B. (1955). Multiple range and $F$ tests Biometrics, 11: 1-42.

Ebeling, W. (2002). Pests of stored food products. In: Urban Entomology, U.C., and Riverside. pp. 1-43. Leowest@Ucracl.ucr.edu.

Ezz, E. (1976). Studies of damage in some stored grains due to infestation with certain insects. PhD. Thesis, Fac. Agric .Cairo Univ.

FAO (2013) "Provisional 2011 production data," Food and Agriculture Organization Online Statistical Databases.

Garcia-Lara, S., D.J. Bergvinson, A.J. Burt, A.I. Ramputh, D.M.D. Pontones and J.T. Arnason, (2004). The role of pericarp cell wall components in maize weevil resistance. Crop Sci., 44: 1546-1552. 
Giga D.P and U.M. Mazarura (1991). Levels of resistance to the maize weevil, Sitophilus zeamais (Motsch.) in exotic, local open pollinated and hybrid maize germplasm Insect Sci. Appl. 12: 159-169.

Giga, D.P., S. Mutemerewa, G. Moya and D. Neeley, (1991). Assessment and control of losses caused by insect pests in small farmers stores in Zimbabwe. Crop Prot., 10: 28292.

Gwinner, J., R. Harnish and 0. Muck, (1996). Manual on the Prevention of Post-Harvest Grain Loss. GTZ, Eschborn, Germany, pages: 334.

Hill, D.S., (1990). Pests of Stored Products and their Control. Belhaven Press, London.

Horber E (1988). Methods to detect and evaluate resistance in maize to seed insects in the field and in storage. In. Towards insect resistance maize for the third world: Proceedings of international symposium on methodologies for developing host plant resistance to maize insects. pp. 140-150. CYMMYT, El Batan, Mexico D.F. CYMMYT.

Lohar, M.K.,S.W.Hussainy,G.M.Juno,A.G.Lanjar and A.A.Shah (1997). Estimation of quantitative losses of wheat, rice and maize caused by Tribolium castaneum (Herbst) under laboratory conditions. Pak. Entomol., 19: 32-35.

Makate N. (2010) "The susceptibility of different maize varieties to post harvest infestation by Sitophilus zeamais (Motsch.) (Coleoptera: Curculionidae," Scientific Research and Essay, 5: 30-34.

Rees, D.P., (1995). Coleoptera. In: Subramanyam, Bh., Hagstrum, D.W. (Eds.), Integrated Management of Insects in Stored Products.Marcel Dekker, New York, pp.1-39.

Samson, P.R. and P.J. Parker (1989). Laboratory studies on protectants for control of Coleoptera in maize.J. Stored Prod.Res.25, 49-55.

SAS (2008) . SAS/STAT 9.2 Version Users Guide. SAS institute Inc., Gary, North Carolina, USA.

Tadesse, A. (1991).The biology, significance and control of the maize weevil, Sitophilus zeamais Motsch. (Coleoptera:Curculionidae) on stored maize. M.Sc. Thesis, AUA, Alemaya University of Agriculture, Alemaya, Ethiopia.

Tefera, T., S. Mugo and P. Likhayo, (2011). Effects of insect population density and storage time on grain damage and weight loss in maize due to the maize weevil Sitophilus zeamais and the larger grain borer Prostephanus truncatus. Afr. J. Agric. Res., 6: 2249-2254. 
Awadalla,S.S. et al.

Sitophilus تأثثير أصناف الذره المختلفه على الاصابه بحشرة سوسة الارز oryzae (L) سمير صالح عوض الله * ، جمال محمد محمود زايد ** ، احمد راثد احمد * و

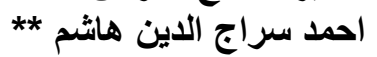

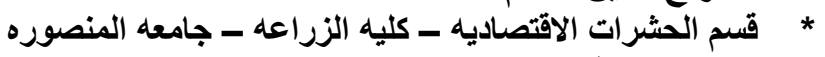

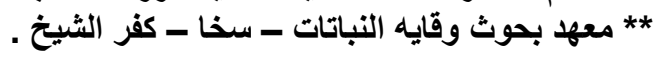

أجريت هذه الدراسه لمعرفة مدى ثأثير أصناف الذره المختلفه على الاصابه بسوسة الارز

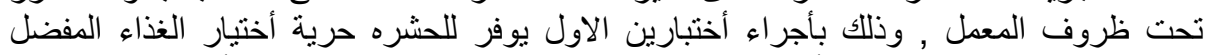

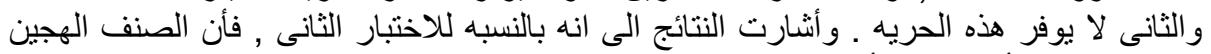

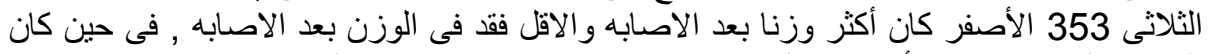

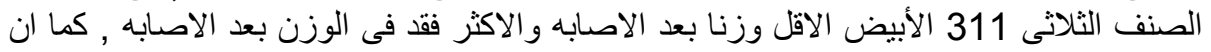

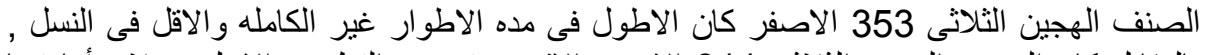

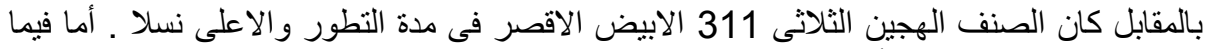

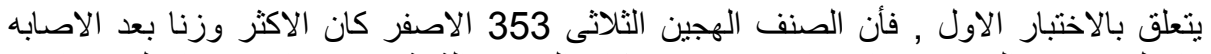

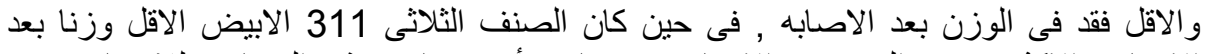

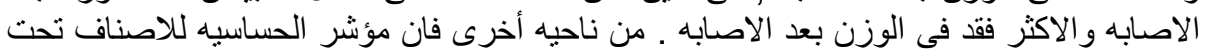

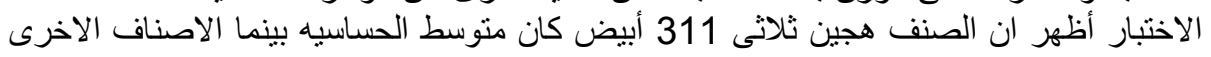
كانت متوسطة المقاومه .

كلية الزراعة - جامعة المنصورة - ملية قام بتحكيم البحث كلية الزراعة - جامعة سوهاج أ. أد / عادل حسن حسن عبد البحث علام

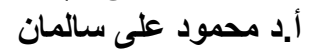

